NOTE

\title{
Evidence of spatial structuring of eastern South Pacific humpback whale feeding grounds
}

\author{
J. Acevedo ${ }^{1{ }^{*}}$, D. Haro ${ }^{2}$, L. Dalla Rosa ${ }^{3}$, A. Aguayo-Lobo ${ }^{4}$, R. Hucke-Gaete ${ }^{2,5}$, \\ E. Secchi ${ }^{3}$, J. Plana ${ }^{6}$, L. A. Pastene ${ }^{7}$ \\ ${ }^{1}$ Centro de Estudios del Cuaternario de Fuego-Patagonia y Antártica (Fundación CEQUA), 21 de Mayo 1690, Casilla 727, \\ Punta Arenas, Chile \\ ${ }^{2}$ Centro Ballena Azul (CBA), c/o ICML, UACh, Casilla 567, Valdivia, Chile \\ ${ }^{3}$ Instituto de Oceanografia, Universidade Federal do Rio Grande - FURG, Río Grande, RS 96201-900, Brasil \\ ${ }^{4}$ Instituto Antártico Chileno (INACH), Departamento Científico, Plaza Muñoz Gamero 1055, Punta Arenas, Chile \\ ${ }^{5}$ Instituto de Ciencias Marinas y Limnológicas, Universidad Austral de Chile, Casilla 567, Valdivia, Chile \\ ${ }^{6}$ Ramón Menéndez Pidal 0294, Punta Arenas, Chile \\ ${ }^{7}$ Institute of Cetacean Research, Toyomi 4-5, Chuo-ku, Tokyo 104-0055, Japan
}

\begin{abstract}
The eastern South Pacific humpback whale population winters primarily off Colombia and Ecuador, extending northward to the coasts of Panama and Costa Rica. It migrates south to the Fueguian Archipelago and Antarctic Peninsula waters for feeding during the austral summer. In recent years, however, humpback whales have also been observed feeding in the Corcovado Gulf, in the northern Chilean Patagonian channels, during the austral summer and fall. We examine photographically identified humpback whales in order to determine interchange or isolation of these aggregations. The apparent absence of movements of identified humpback whales among the 3 summering areas, and the differences in the proportion of white/black coloration on the fluke, suggest that each locality corresponds to a discrete feeding area for eastern South Pacific humpback whales.
\end{abstract}

KEY WORDS: Humpback whale · Eastern South Pacific $\cdot$ Corcovado Gulf $\cdot$ Fueguian Archipelago • Southern Ocean · Feeding ground

\section{INTRODUCTION}

The humpback whale Megaptera novaeangliae is a cosmopolitan cetacean, widely distributed throughout all oceans of the world (Clapham \& Mead 1999). In the Southern Hemisphere, 7 geographically isolated humpback whale breeding stocks $(\mathrm{A}-\mathrm{G})$ are recognized by the IWC (2005), all of which migrate to discrete feeding areas located in the Southern Ocean (Fig. 1).

Traditionally, the eastern South Pacific (ESP) humpback whale population (also termed stock G by the International Whaling Commission, IWC) has been described as feeding in productive waters off the west coast of the Antarctic Peninsula during the austral summer season (Kellogg 1929, Mackintosh 1965, Dawbin 1966). In recent years, another humpback whale feeding area has been identified further north, around the Fueguian Archipelago, in the Magellan Strait $\left(53^{\circ} 30^{\prime} \mathrm{S}\right)$, Chile (Gibbons et al. 2003, Acevedo 2005, Acevedo et al. 2006). Likewise, an increasing number of humpback whales exhibiting feeding activities have also been observed during the austral summer/fall months in the Corcov- 


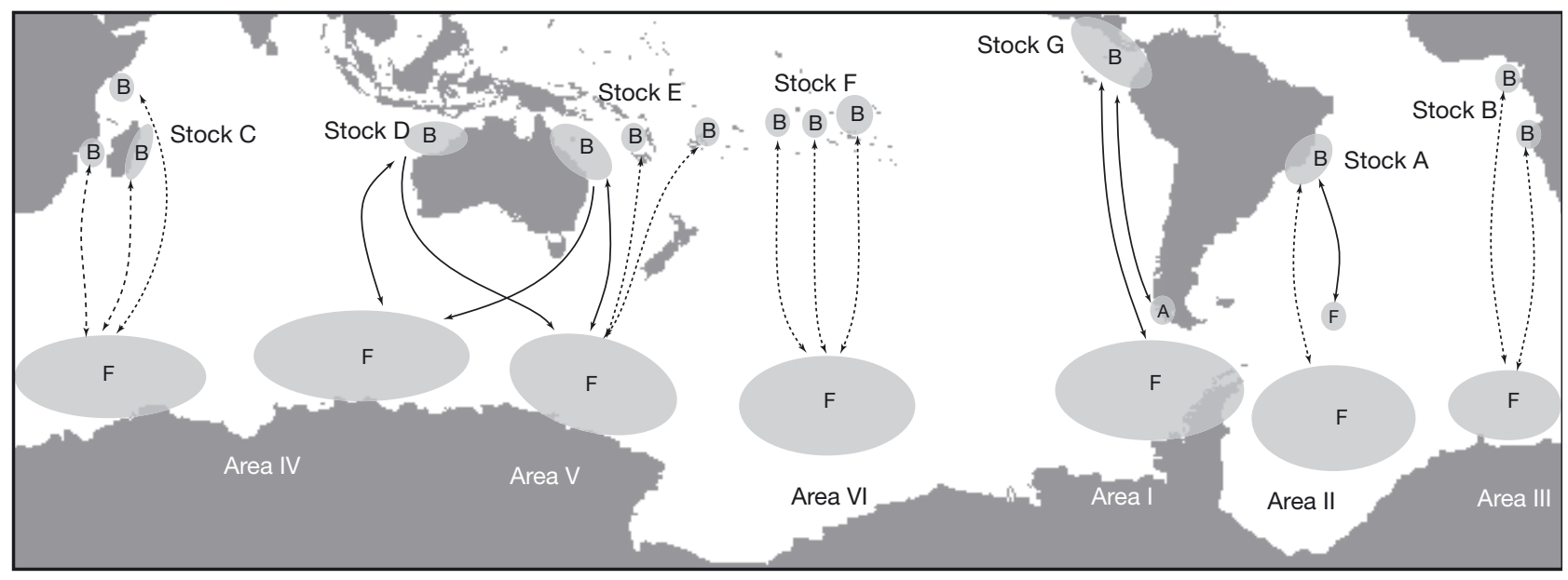

Fig. 1. Illustration of humpback whale breeding stocks (A-G) recognized by the International Whaling Commission, including details of breeding areas (B), feeding areas (F), known migratory destinations (solid arrows) and possible migratory destinations (dotted arrows). Antarctic areas (I-VI) represent historical stock boundaries for baleen whales

ado Gulf $\left(43^{\circ} 53^{\prime} \mathrm{S}\right)$. Corcovado Gulf is located 1080 $\mathrm{km}$ north of the Magellan Strait, suggesting that this corresponds to another discrete feeding area for this population (Haro 2009, Hucke-Gaete et al. 2013). An alternative interpretation would be that the Corcovado Gulf may correspond to a transitory area during the whales' migration further south to the Fueguian Archipelago or the Antarctic Peninsula. Here we examine the relationship between photographically identified humpback whales in order to determine the degree of interchange or isolation among these 3 summer aggregations. Such information on possible sub-structuring of the population and stock identity is required to ensure appropriate use of capture-recapture models for reliable estimation of population size in the ESP, and to resolve central questions on one of the least understood humpback whale populations.

\section{MATERIALS AND METHODS}

Individual humpback whales were identified from photographs, based on unique pigmentation patterns and/or permanent scars on the ventral side and marks on the trailing edge of the fluke (Katona et al. 1979). Only medium- to high-quality fluke photographs were used in the comparisons, based on focus, angle, clarity, contrast, and recognition (distinctive patterns, marks, or scars) (Mizroch et al. 1990, Friday et al. 2000). Six photo-identification catalogs were used, covering 3 relevant localities: Corcovado Gulf (CG), Fueguian Archipelago (FA), and Antarctic Peninsula (AP). In addition, some identified whales from Wide Channel $\left(49^{\circ} 50^{\prime} \mathrm{S}\right)$ to Smyth Channel $\left(52^{\circ} 44^{\prime} \mathrm{S}\right)$, north of Magellan Strait, were included as part of the FA region. The surveyed areas are described in Table 1 and illustrated in Fig. 2.

Table 1. Total number of identified humpback whales and number of whales used in the comparisons of 6 photo-identification catalogs from 3 different study areas. CBA: Centro Ballena Azul; CEQUA: Fundación Centro de Estudios del Cuaternario; INACH: Instituto Antárctico Chileno

\begin{tabular}{|c|c|c|c|c|}
\hline Institution & $\begin{array}{l}\text { No. } \\
\text { Total }\end{array}$ & $\begin{array}{l}\text { of whales } \\
\text { Examined }\end{array}$ & $\begin{array}{l}\text { Sampling } \\
\text { years }\end{array}$ & Location \\
\hline $\begin{array}{l}\text { CBA \& Universidad } \\
\text { Austral de Chile }\end{array}$ & 44 & 34 & 2003-2011 & $\begin{array}{l}\text { Corcovado Gulf, mouth of Guafo and Moraleda } \\
\text { Channel, Chile }\end{array}$ \\
\hline CEQUA & 152 & 142 & 2003-2012 & $\begin{array}{l}\text { Magellan Strait and adjacent waters (Fueguian } \\
\text { Archipelago), including Wide and Smyth Channel, Chile }\end{array}$ \\
\hline $\begin{array}{l}\text { INACH, Projeto Baleias/ } \\
\text { PROANTAR, CEQUA } \\
\text { and contributors }\end{array}$ & 798 & 718 & 1982-2010 & $\begin{array}{l}\text { Western (from Bransfield to Grandidier Channel) } \\
\text { and eastern Antarctic Peninsula waters }\end{array}$ \\
\hline Total photos & 994 & 894 & & \\
\hline
\end{tabular}




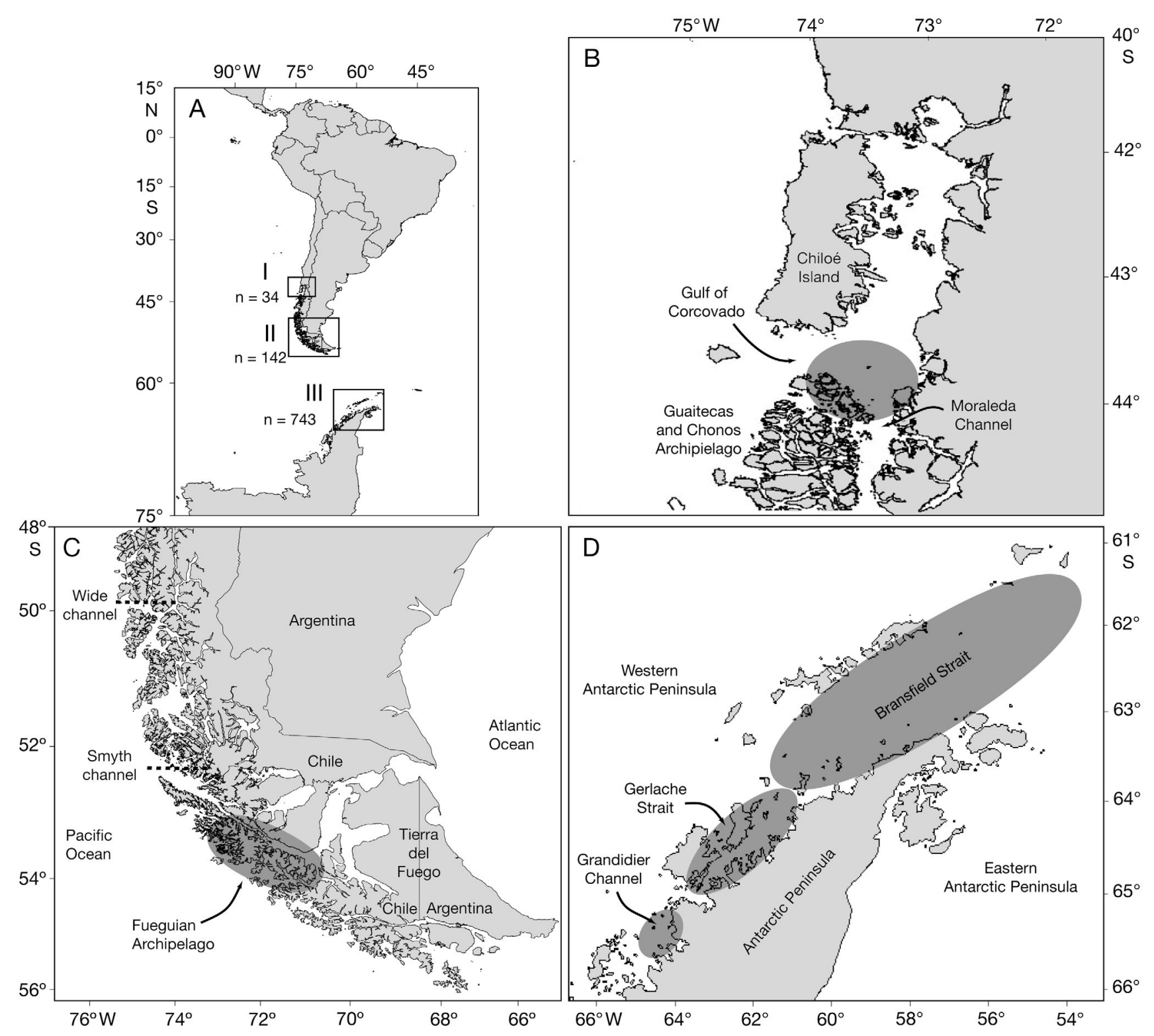

Fig. 2. (A) The 3 study areas with the corresponding number of identified whales (n) (B-D) Details of study areas (I, II, III, respectively); shaded ellipses delimit the main photo-identification areas

The only abundance estimate for this population on feeding grounds was obtained for the Bransfield Strait area, with a derived abundance of 865 individuals $(95 \% \mathrm{CI}=656$ to 1141$)$. However, this represents only a fraction of the AP feeding unit (Secchi et al. 2011). Population sizes for the FA and CG regions are unknown. However, the high rates of annual return to FA (74.8 to $83.6 \%$ ) (Acevedo et al. 2006, 2013, Mora 2011) suggest a small unit of humpback whales, with no more than 200 individuals visiting this area. In the CG region, several individuals were sighted from different platforms between 2000 and 2010, but these could include many duplicate sight- ings, obtained from platforms operating simultaneously. Photo-identification efforts from boat-based surveys resulted in 34 individual whales identified by their fluke coloration pattern in the CG region. Ten of these individuals were re-sighted within a maximum of $5 \mathrm{yr}$, resulting in a $31 \%$ return rate (Haro 2009, Hucke-Gaete et al. 2013). Although the effort dedicated to humpback whales in CG has fluctuated over the years, the available evidence suggests that this humpback whale aggregation is smaller than the FA aggregation.

For CG, one catalog was used (CBA; for full catalog names see Table 1) containing 34 identified whales. 
For the FA feeding area, the CEQUA catalog was used, including 142 identified whales. For the AP feeding area, 3 catalogs (INACH, PROANTAR/Projeto Baleias and CEQUA) and a small data set from one of us (J.P.) were used, totaling 798 identified whales obtained by different research groups between 1982 and 2010. For the AP feeding area, duplicate whales were discarded, reducing the total number of whales examined to 718 identified whales. The comparisons of identified whales between the 3 localities were completed using SAIR-BJ (Acevedo 2012), software developed by CEQUA researchers. The SAIR-BJ software selects subsets of fluke photographs for visual comparison. A manual pairwise visual comparison of the CG and FA catalogues was also performed independently by 2 researchers experienced with these localities.

We also determined the proportion of white and black coloration present on the ventral surface of humpback whale flukes for the 3 geographic areas. Fluke photographs were visually assessed by 2 independent researchers, and coloration rank values were assigned ranging from 1 (all white) to 5 (all black) (sensu Rosenbaum et al. 1995). The assigned rank variation of photographs used between researchers was $5.23 \%$, and average values of each coloration rank were used for each locality in the analysis. The distribution of pigmentation classes among humpback whale aggregations was analyzed using the nonparametric Kruskal-Wallis test statistics and the nonparametric Newman-Keuls test. Both tests use rank ordering (Zar 1984, Rosenbaum et al. 1995).

\section{RESULTS AND DISCUSSION}

No matches were found between humpback whales identified in the FA and AP catalogs. This evidence confirms the previously suggested hypothesis that the central area of the FA (Magellan Strait) represents a discrete migratory destination for humpback whales of the ESP population during the austral summer (Acevedo 2005, Acevedo et al. 2007). This finding is also supported by the differences found in mitochondrial DNA (mtDNA) between humpback whales from both localities, which suggest a genetic sub-structuring within this population (Olavarría et al. 2006).

More interestingly, no matches were found among the humpback whales identified in the CG and those in the FA and AP feeding areas. Despite the small number of identified whales in northern Chilean Patagonia, these results suggest that at least part of the ESP humpback whale population also migrates to Corcovado Gulf and remains in northern Chilean Patagonia $\left(43^{\circ} \mathrm{S}\right)$ throughout the summer and early autumn. Although blue whales are the primary research focus in the CG (Hucke-Gaete 2004, Hucke-Gaete et al. 2004), some residence time data indicate that humpback whales remain up to 32 d (Haro 2009, Hucke-Gaete et al. 2013).

Previously, only one individual match had been reported between northern Patagonia and the central area of Fueguian Archipelago during an austral summer season (Capella et al. 2008). This individual, a mother with her calf, was sighted on 8 February 2008 off northwestern Chiloé Island (at $251 \mathrm{~km}$ north of CG) and re-sighted on 18 March of the some year in the Magellan Strait (Fueguian Archipelago). However, this individual (mother) had been periodically sighted each year (from 2004 to 2010) in the latter feeding locality. The migratory behavior regularity of this individual suggests that the northwestern Chiloé locality represents an area of coastal transit for some individuals moving to or from feeding grounds.

Results of fluke pigmentation rates differed significantly among the 3 humpback whale summer aggregations $(H=12.54, \mathrm{p}=0.002)$. Pairwise comparisons showed that each locality also differed significantly in fluke pigmentation patterns (Newman-Keuls test, $\mathrm{p}<0.05)$. Darker pigmentation patterns were more common for the CG humpback whales $(\bar{x}=3.16)$ than on those from FA $(\bar{x}=2.50)$ and the AP regions $(\bar{x}=2.36$; Table 2$)$. This pattern shows an apparent latitudinal trend in ventral fluke pigmentation of humpback whales across the feeding areas examined in the ESP, ranging from darker pigmentation in mid-latitude areas to lighter pigmentation in southern latitudes.

Such a latitudinal trend in fluke coloration has been reported for the central and eastern North Pacific (Baker et al. 1986) and the North Atlantic

Table 2. Frequency of humpback whale fluke pigmentation patterns in the 3 study areas, by coloration category, where $1=$ lightest and $5=$ darkest

\begin{tabular}{|c|c|c|c|c|c|c|c|}
\hline \multirow[t]{2}{*}{ Area } & \multirow{2}{*}{$\begin{array}{c}\text { Total } \\
\text { (n) }\end{array}$} & \multicolumn{6}{|c|}{ Fluke pigmentation by category $(\%)$} \\
\hline & & 1 & 2 & 3 & 4 & 5 & Average \\
\hline Corcovado Gulf & 34 & 19.1 & 22.1 & 5.9 & 29.4 & 23.5 & 53.16 \\
\hline Fueguian Archipelago & 142 & 29.0 & 31.1 & 9.5 & 21.6 & 8.8 & 2.50 \\
\hline Antarctic Peninsula & 744 & 31.5 & 33.9 & 10.4 & 15.9 & 8.3 & 32.36 \\
\hline
\end{tabular}


(Allen et al. 1994) populations. In the North Atlantic, humpback whale fluke coloration in the Gulf of Maine (the closest feeding area to the West Indies breeding ground) was significantly darker than on whales photographed near Greenland (the farthest feeding area from this breeding ground), which were also characterized by significantly lighter-colored flukes than whales from the other known feeding stocks of this population (Allen et al. 1994). These similarities in coloration patterns suggest that humpback whales in the ESP also form a 'structured stock', consisting of 3 geographically distinct 'feeding herds'.

Despite the fact that the relatively low number of identified whales on CG could induce the lack of detection of some migratory movements to southernmost feeding areas, as well as a bias in the fluke coloration proportions of humpback whales from the CG summer aggregation, our findings provide additional information to the current knowledge on ESP humpback whales, and supporting evidence of a third mid-latitude feeding area in the Chiloense Ecoregion (Hucke-Gaete et al. 2013). If the current description of population structure among these austral summer aggregations is correct, our result is also relevant in the context of population trend assessment and conservation. Therefore, additional photoidentification efforts and skin tissue sampling are urged, especially in the Corcovado Gulf area.

Acknowledgements. We are grateful to Fundación CEQUA, Universidad Austral de Chile, Gobierno Regional de Los Lagos (Chile), World Wide Fund for Nature (WWF-Chile), Whitley Fund for Nature, Rufford Small Grants Foundation, Avina Foundation, Whale \& Dolphin Conservation Society, Society for Marine Mammalogy, Instituto Antártico Chileno, Brazilian Council for Scientific and Technological Development (CNPq), Ministry of Environment - Chile and Brazil, and Inter-ministerial Commission for the Resources of the Sea (CIRM)/Brazilian Navy, for providing funding and continuous support. The authors thank all colleagues and volunteers that participated in the field, and Ben Wallis for the trip to Antarctic onboard the R/V 'Australis' yacht in summer 2010. SAIR-BJ software and this manuscript were financially supported by INACH Project G-16-10 and Grant R07K1002 Conicyt Regional/GORE Magallanes. This is publication no. 45 of the Marine Mammal Research Program of Fundación CEQUA.

\section{LITERATURE CITED}

Acevedo J (2005) Distribución, fidelidad, residencia e identidad poblacional de la ballena jorobada, Megaptera novaeangliae, que se alimentan en las aguas del Estrecho de Magallanes, Chile. MSc dissertation, Universidad de Magallanes, Punta Arenas
Acevedo J (2012) SAIR-BJ: un sistema computacional de recaptura asistida para ballenas jorobadas del Pacífico Suroriental. IX Congress of Marine Sciences, MarCuba 2012. Habana (Abstract)

Acevedo J, Aguayo-Lobo A, Pastene LA (2006) Filopatría de las ballenas jorobadas (Megaptera novaeangliae), al área de alimentación del Estrecho de Magallanes. Rev Biol Mar Oceanog 41:11-19

> Acevedo J, Rasmussen K, Félix F, Castro C and others (2007) Migratory destinations of humpback whales from the Magellan Strait feeding ground, Southeast Pacific. Mar Mamm Sci 23:453-463

Acevedo J, Mora C, Aguayo-Lobo A (2013) Sex-related site fidelity of Megaptera novaeangliae to the Fueguian Archipelago feeding area, Chile. Mar Mamm Sci (in press) doi:10.1111/mms.12048

Allen J, Rosenbaum HC, Katona SK, Clapham PJ, Mattila DK (1994) Regional and sexual difference in fluke pigmentation of humpback whales (Megaptera novaeangliae) from the North Atlantic Ocean. Can J Zool 72: 274-279

Baker CS, Herman LM, Perry A, Lawton WS and others (1986) Migratory movement and population structure of humpback whales (Megaptera novaeangliae) in the central and eastern North Pacific. Mar Ecol Prog Ser 31: 105-119

Capella J, Galletti B, Gibbons J, Cabrera E (2008) Coastal migratory connections of humpback whales, Megaptera novaeangliae Borowski, 1781, in southern Chile. An Inst Patagon 36:13-18

Clapham PJ, Mead JG (1999) Megaptera novaeangliae. Mamm Species 604:1-9

Dawbin WH (1966) The seasonal migratory cycle of humpback whales. In: Norris K (ed) Whales, dolphins and porpoises. University of California Press, Berkeley, CA, p 145-170

Friday N, Smith TD, Stevick PT, Allen J (2000) Measurement of photographic quality and individual distinctiveness for the photographic identification of humpback whales, Megaptera novaeangliae. Mar Mamm Sci 16:355-374

Gibbons J, Capella JC, Valladares C (2003) Rediscovery of a humpback whale (Megaptera novaeangliae) feeding ground in the Straits of Magellan, Chile. J Cetacean Res Manag 5:203-208

Haro D (2009) Identificación individual de ballenas jorobadas, Megaptera novaeangliae (Borowski, 1781), en el golfo Corcovado, Patagonia Norte, Chile: 2003-2009. Undergraduate dissertation, Universidad Austral de Chile, Valdivia

Hucke-Gaete R (2004) Distribución, preferencia de hábitat y dinámica espacial de la ballena azul en Chile: 19972004. PhD dissertation, Universidad Austral de Chile, Valdivia

Hucke-Gaete R, Osman LP, Moreno CA, Findlay KP, Ljungblad DK (2004) Discovery of a blue whale feeding and nursing ground in southern Chile. Proc Biol Sci 271(Suppl):S170-S173

Hucke-Gaete R, Haro D, Torres-Florez JP, Montecinos Y, Viddi F, Bedriñana-Romano L, Nery M (2013) A historical feeding ground for humpback whales in the eastern South Pacific revisited: the case of northern Patagonia, Chile. Aquatic Conserv Mar Freshw Ecosyst, doi:10. 1002/aqc. 2343

IWC (International Whaling Commission) (2005) Report of the Scientific Committee, Annex H, Report of the sub- 
committee on other Southern Hemisphere whale stocks. J Cetacean Res Manag 7(Suppl):235-246

Katona SK, Baxter B, Brazier O, Kraus S, Perkins J, Whitehead $\mathrm{H}$ (1979) Identification of humpback whales by fluke photographs. In: Winn HE, Olla BL (eds) Behavior of marine animals. Vol 4. Plenum Press, New York, NY, p 33-34

Kellogg R (1929) What is known of the migration of some of the whalebone whales. Smithsonian Institution. Ann Rep Board of Regents 1928:467-494

Mackintosh NA (1965) The stocks of whales. Fishing News, London

Mizroch SA, Beard JA, Lynde M (1990) Computer assisted photo-identification of humpback whales. Rep Int Whal Comm 12:63-70

Mora C (2011) Situación temporo-espacial de la ballena jorobada en el sector central del Archipiélago Fueguino, Chile. Undergraduate dissertation, Universidad de Magallanes, Punta Arenas

Editorial responsibility: Jaume Forcada, Cambridge, UK
Olavarría C, Aguayo-Lobo A, Acevedo J, Medrano L, Thiele D, Baker CS (2006) Genetic differentiation between two feeding areas of the Eastern South Pacific humpback whale population. Update on SC/57/SH3. Workshop on the Comprehensive Assessment of Southern Hemisphere Humpback Whales. IWC, Hobart

Rosenbaum HC, Clapham PJ, Allen J, Nicole-Jenner M and others (1995) Geographic variation in ventral fluke pigmentation of humbpack whale Megaptera novaeangliae populations worldwide. Mar Ecol Prog Ser 124: $1-7$

Secchi E, Dalla-Rosa L, Kinas PG, Nicolette RF, Rufino AMN, Azevedo AF (2011) Encounter rates and abundance of humpback whales (Megaptera novaeangliae) in Gerlache and Bransfield Straits, Antarctic Peninsula. J Cetacean Res Manag 3:107-111

Zar JH (1984) Biostatistical analysis, 2nd edn. Prentice-Hall, Englewood Cliffs, NJ

Submitted: March 26, 2013; Accepted: August 7, 2013 Proofs received from author(s): October 21, 2013 